\title{
MENGATASI KENAKALAN REMAJA PADA MASA TRANSISI
}

\author{
Erhansyah \\ Guru SMP Negeri 1 \\ Muara Muntai \\ esaalbanjari@gmail.com
}

\begin{abstract}
The teenage transition period is a period of change in behavior that is felt differently. Teenagers have conditions and energy that are very prime and have the potential and reality of fighting spirit and high power of patriotism. In this transition period, adolescents must be conditioned in a positive direction so that adolescents grow into mature adults who behave noble. The transitional period of adolescents is prone to delinquency, both those with the potential for criminal acts and ordinary crime. In many cases events that occur many parents who complain, even troubled, because their children who had stepped on the early teens became stubborn, difficult to manage, young huffed and daydreaming. In the context of the behavior of students at school, the ability of the teacher to carry out his role well, forming the personal of the students so that they grow well, very necessary in the learning process that is right for these students. The role of the teacher must be in the form of guidance services for those who experience difficulties in the transition stage, which in its development is one of the special handling. This means that students who are classified as having problems at the top level need to be prioritized. The reason for choosing the right approach by the teacher is that the transition difficultiesexperienced by the child can be handled optimally and the teacher recognizes the true disturbances.

For this reason, efforts to overcome adolescent behavior during this transition period can be carried out preventive, curative and refresive efforts. Through the approach to Islamic education carried out with a general effort namely Islamic education during the womb, after birth given love and environmental education in the family and in the community. Special efforts are carried out with supervision, guidance and counseling as well as specific actions that are justified by the applicable legislation.
\end{abstract}

Keywords: Delinquency, Juvenile, Transition 


\section{PENDAHULUAN}

Ketika usia anak beranjak ke jenjang sekolah menengah pertama (SMP) atau sederajat, maka pada masa ini ada perubahan perilaku yang dirasakan berbeda dibanding pada saat mereka masih duduk di sekolah dasar (SD). Masa setelah sekolah dasar dan menuju masa sekolah menengah (SMP) adalah masa siswa ini mulai menginjak masa awal remaja. Masa remaja mengandung beraneka ragam kesan, ada yang mengatakan masa remaja seperti layaknya masa perkembangan lainnya.

Dalam banyak hal masa remaja merupakan masa yang selalu menyusahkan, tetapi ada yang lebih positif bahwa masa remaja harus dimanfaatkan sebagai salah satu sumber daya manusia. Hal ini dimaklumi karena masa ini energi yang mereka miliki masih dalam kondisi prima sehingga bila dikondisikan secara positif maka tentu akan berdampak positif pula. Demikian pula sebaliknya bila segala potensi, fitalitas, semangat patriotis, harapan bangsa sebagai penerus generasi tetapi bila pertumbuhan remaja tidak dikondisikan terutama oleh orang tua dan tumbuh dengan sendiri tentu harapan itu masih dalam tanda tanya. Kurangnya perhatian dari orang tua mengenai jiwa anak dapat menimbulkan perselisihan paham, akhirnya timbul konflik antara remaja dengan orang tua dan selanjutnya terjadilah kesulitan remaja dalam menapak jalur hidupnya.

Kesulitan dikarenakan mereka baru saja pada masa ini melepaskan status barunya yaitu lepas dari kanak-kanak menuju dewasa. Sejak kanak-kanak menjadi dewasa untuk dapat menyesuaikan diri dengan lingkungan sedangkan untuk memenuhi kebutuhan dari dalam dan dari luar anak perlu adanya kecakapan, kemampuan untuk dapat diterima di linkungan. Dalam masa peralihan ini mereka seakan-akan tidak menentu, kadang-kadang masih terasa sebagai siswa sekolah dasar dan dianggap terlalu besar untuk anak-anak, tetapi sering disebut juga terlalu kecil untuk orang dewasa. Pemahaman mereka seperti ini tentu memerlukan penjelasan dan pemahaman agar mereka dapat melalui masa ini dengan kondisi yang terkendali. Status yang dilekatkan pada diri mereka yang belum permanen diakui keberadaannya menyebabkan mereka mendapatkan masalah baru dalam menentukan sikapnya sehari hari. Senanda dengan ini menurut Zakiah Drajat remaja adalah : masa peralihan di antara masa kanakkanak dan dewasa. Dalam masa ini anak mengalami masa pertumbuhan dan masa 
perkembangan fisiknya maupun perkembangan psikisnya. Mereka bukanlah anakanak baik bentuk badan ataupun cara berfikir atau bertindak, tetapi bukan pula orang dewasa yang telah matang. Lebih jauh, remaja adalah saat dimana ia mencari penerimaan dari lingkungan, terutama dari teman sebaya atau sekelompok. (Daradjat, 2000:23)

Dalam banyak kasus peristiwa yang terjadi banyak orang tua yang mengeluh, bahkan bersusah hati, karena anaknya yang telah menginjak awal remaja itu menjadi keras kepala, sukar diatur, mudah tersinggung dan suka melamun.

Di samping itu juga tidak sedikit usia anak sekolah menengah ini yang merasa tidak mendapat tempat dikalangan orang-orang dewasa, dengan demikian para remaja mencoba mencari jalan keluar, mereka ingin hidup lepas dan bebas dari segala ikatan. Maka timbullah kelompok-kelompok anak-anak yang kadang kala bersifat destruktif yang melanggar nilai dan norma yang mengarah pada kenakalan, seperti yang dikemukakan oleh Nurbani YS dan A Ariyadi W bahwa :"Perilaku khusus anak menyangkut konsep nilai dan norma, suatu perbuatan dapat dikatakan nakal bila berkaitan dengan pelanggaran nilai dan norma yang berlaku dalam masyarakat. Pelanggaran dapat berarti menyimpang, bertentangan bahkan merusak norma yang sudah ada”. (Nurbani YS, 2002:88)

Dalam konteks perilaku siswa disekolah maka kemampuan guru dapat menjalankan perannya dengan baik, membentuk pribadi peserta didiknya sehingga tumbuh berkembang dengan baik, sangat diperlukan dalam proses pembelajaran yang tepat bagi siswa tersebut. Peran guru tentulah berupa layanan bimbingan terhadap mereka yang mengalami kesulitan dalam tahap transisi yang dalam perkembang-annya merupakan salah satu penanganan ynag tergolong khusus. Artinya siswa yang tergolong memiliki gangguan pada level atas perlu diprioritaskan. Alasan dipilihnya pendekatan yang tepat oleh guru dimaksudkan agar kesulitan transisi yang dialami anak dapat ditangani secara optimal dan guru mengenali benar gangguan yang sebenarnya.

\section{HASIL DAN PEMBAHASAN}

\section{A. Pengertian Transisi}

Masa remaja menunjukkaan dengan jelas sifat transisi atau peralihan karena remaja belum memperoleh status dewasa dan tidak lagi memiliki status anak. 
(Kartini Kartono,1986:26) Sementara itu, Prastuti berpendapat bahwa "remaja merupakan masa transisi atau peralihan dari masa kanak-kanak menuju masa dewasa”. (Endang. IKIP Malang. 1997:1) Sedangkan menurut Kartini Kartono masa remaja adalah suatu periode transisi dari masa awal anak anak hingga masa awal dewasa, yang dimasuki kira kira 10 hingga 12 tahun dan berakhir pada usia 18 tahun hingga 22 tahun. (Kartini, 1986: 25) Pandangan lain dikemukakan oleh Daradjat bahwa: "Remaja adalah usia transisi. Seseorang individu telah meninggalkan usia kanak-kanak yang lemah dan penuh ketergantungan, akan tetapi belum mampu ke usia yang kuat dan penuh tanggung jawab, baik terhadap dirinya maupun terhadap masyarakat, banyaknya masa transisi ini tergantung kepada keadaan dan tingkat social masyarakat dimana ia hidup. Semakin maju masyarakat semakin panjang usia remaja, karena ia harus mempersiapkan diri untuk menyesuaikan diri dalam masyarakat yang banyak syarat dan tuntutannya". (Sofyan, 2005:23)

B. Masa Remaja

Dari beberapa pendapat para ahli sebagaimana dikemukakan di atas bahwa masa transisi itu adalah masa yang dialami oleh para remaja, karenanya maka makna remaja dan transisi itu menjadi suatu yang tidak bisa dipisahkan. Membicarakan remaja maka makna transisi juga akan masuk dalam pembahasan demikian pula sebaliknya masa transisi itu sendiri juga membahas masalah remaja.

Menurut Soekanto masa remaja ada empat bagian, yaitu masa pra remaja 10-12 tahun, masa remaja awal 12-15 tahun, masa remaja pertengahan 15-18 tahun, dan masa remaja kahir 18-21 tahun. (Soekanto,1987:44) Sementara menurut Hurlock sebagaimana dikutif Al-Mighwar, masa remaja dapat dikelompokkan menjadi dua, yakni masa remaja awal, dan masa remaja akhir. Masa remaja awal adalah dalam rentangan usia 13 atau 14 tahun sampai 17 tahun. Sedangkan masa remaja akhir adalah dalam rentangan usia 17 tahun sampai 21 tahun. (Muhammad, 2006: 60) Sedangkan menurut Andi Mappiare, masa remaja adalah berlangsung antara usia 12 tahun sampai dengan 21 tahun bagi wanita, dan 13 tahun sampai dengan 22 tahun bagi pria. Rentang usia remaja tersebut dapat dibagi menjadi dua bagian, yaitu usia 12/13 sampai dengan 17/18 tahun adalah remaja awal, dan usia 17/18 tahun sampai 21/22 tahun, yaitu remaja akhir. (Andi, 
1998: 22) Selanjutnya, menurut pandangan Piaget sebagaimana dikutif dalam AlMighwar, "Secara psikologis masa remaja adalah usia saat individu berintegrasi dengan masyarakat dewasa, usia saat anak tidak lagi merasa di bawah tingkat orang-orang yang lebih tua, melainkan berada dalam tingkatan yang sama, sekurang-kurangnya dalam masalah hak Transformasi, intelektual yang khas dari cara berpikir remaja ini memungkinkannya untuk mencapai integrasi dalam hubungan social orang dewasa, yang kenyataannya merupakan cirri khas yang umum dari periode perkembangan ini”. (Muhammad, 2006:56)

Dari beberapa pendapat tersebut persamaan terdapat pada penentuan umur, bahwa umur 10 - 21 tahun dikatagorikan sebagai remaja, yang berbeda adalah pada penentuan fase fase umur remaja itu sendiri yang terdiri dari penentuan interval pada setiap fase tersebut. Fase fase tersebut terdiri dari masa remaja awal, masa remaja pertengahan dan masa remaja akhir.

C. Bentuk Kenakalan Remaja

Menurut Jansen sebagaimana dikutif Sarwono membagi kenakalan remaja dalam empat jenis, yaitu:

1. kenakalan yang menimbulkan korban fisik pada orang lain seperti perkelahian, perkosaan, perampokan, pembunuhan dan lain-lain,

2. kenakalan yang menimbulkan korban materi seperti perusakan, pencurian, pencopetan, pemerasan dan lain-lain,

3. kenakalan sosial yang tidak menimbulkan korban di pihak orang lain seperti pelacuran dan penyalahgunaan obat,

4. kenakalan yang melawan status misalnya mengingkari status anak sebagai pelajar dengan cara membolos, mengingkari status orang tua dengan cara minggat dari rumah dan membantah perintah orang tua. (Sarlito Wirawan Sarwono, 1989: 200)

Sedangkan menurut Willis, bahwa kadang-kadang sekolah juga penyebab dari timbulnya kenakalan remaja. Hal ini mungkin bersumber dari guru, fasilitas pendidikan, norma-norma tingkah laku. (Sofyan S Willis, 2005: 114)

Kenakalan remaja pada masa ini ada yang digolongkan sudah melanggar norma hukum ada pula yang tidak, sejalan dengan itu menurut Kvaraceus sebagaimana dikutif Mulyono, bahwa ada dua bentuk kenakalan remaja, yaitu: pertama, Kenakalan yang dapat digolongkan pada pelanggaran hukum; kedua, 
Kenakalan yang tidak dapat digolongkan pada pelanggaran hukum. Kenakalan yang tidak dapat digolongkan pada pelanggaran hukum antara lain:

1) berbohong, memutarbalikkan kenyataan dengan tujuan menipu orang atau menutup kesalahan,

2) membolos, pergi meninggalkan sekolah tanpasepengetahuan pihak sekolah,

3) kabur meninggalkan rumah tanpa ijin orang tua atau menentang keinginan orang tua,

4) keluyuran pergi sendiri maupun berkelompok tanpa tujuan, dan mudah menimbulkan perbuatan iseng yng negatif,

5) memiliki dan membawa benda yang membahayakan orang lain, sehingga mudah terangsang untuk mempergunakannya, misalnya pisau dan pistol,

6) bergaul dengan orang yang memberi pengaruh buruk, sehingga mudah terjerat dalam perkara yang benar-benar kriminal,

7) berpesta pora semalam suntuk tanpa pengawasan, sehingga mudah timbul tindakan-tindakan yang kurang bertanggung jawab (amoral dan asusila),

8) membaca buku-buku cabul dan kebiasaan menggunakan bahasa yang tidak sopan, tidak senonoh,

9) turut dalam pelacuran atau melacurkan diri baik dengan tujuan ekonomis maupun tujuan yang lain,

10) berpakaian tidak pantas dan minum-minuman keras atau menghisap ganja sehingga merusak dirinya.

Sedangkan kenakalan yang dapat digolongkan pada pelanggaran hukum dan mengarah kepada tindakan kriminal antara lain : berjudi menggunakan uang, mencuri, menjambret menggunakan kekerasan, penipuan, penggelapan barang, pelanggaran tata susila, pemalsuan surat surat resmi, tindakan anti sosial, perbuatan yang merugikan orang lain, percobaan pembunuhan, pengguguran kandungan, penganiyaan berat yang mengakibatkan kematian seseorang. (B. Mulyono, 1995:22)

Pandangan lain tentang kenakalan remaja dikemukakan oleh Soedarsono (2004 : 86) bahwa suatu perbuatan tergolong kenakalan remaja, jika perbuatan tersebut bersifat melawan hukum, anti sosial, anti susila, dan melanggar normanorma agama yang dilakukan oleh objek yang masih berusia remaja yang menurut 
sebagian psikolog umur 11-21 tahun, maka perbuatan tersebut cukup alasan untuk disebut kenakalan remaja (juvenile delinquency).

Sementara Asiyah menyimpulkan bahwa kenakalan remaja adalah perbuatan anak-anak yang melanggar norma-norma baik norma sosial, norman hukum, norma kelompok, mengganggu ketenteraman masyarakat sehingga yang berwajib mengambil suatu tindakan pengasingan. Kenakalan tersebut dilakukan oleh remaja atau anak dibawah usia 21 tahun. (Asiyah,1996:24)

D. Upaya Menanggulangi Kenakalan Masa Transisi Remaja

Terdapat beberapa hal yang bisa dilakukan untuk mengurangi terjadinya kenakalan pada remaja, diperlukan hal hal sebagai berikut :

1. Upaya preventif

Usaha preventif adalah segala tindakan yang bertujuan mencegah timbulnya kenakalan-kenakalan Usaha pencegahan ini bisa dilakukan secara sistematis terencana dan terarah kepada tujuan untuk menjaga agar kenakalan itu tidak terjadi. Tindakan yang dilakukan orang tua sebelum kenakalan terjadi supaya tindakan kenakalan dapat diredam atau dicegah yaitu dengan cara melalui bimbingan, pengarahan dan ajakan.

2. Upaya Kuratif

Usaha kuratif adalah usaha dalam menanggulangi masalah kenakalan remaja/penyimpangan prilaku. Pencegahan ini dimaksudkan agar kenakalan tidak meluas dan merugikan baik pribadi maupun masyarakat sekitarnya. Tindakan yang dilakukan orang tua setelah terjadinya kenakalan yaitu dengan memberikan penyadaran kepada remaja yang melakukan tindakan menyimpang.

\section{Upaya Refresif}

Usaha represif adalah tindakan untuk menindas dan menahan kenakalan remaja sering mungkin atau menghalangi timbulnya peristiwa kenakalan yang lebih hebat. Tindakan yang dilakukan orang pada saat kenakalan terjadi dan supaya dapat dihentikan yaitu dengan orang tua memberi hukuman kepada remaja yang melanggar tatatertib di sekolah. Hukuman ini dimaksudkan agar tindakan kenakalan siswa tidak berulang lagi.

Sementara itu menurut Sofyan Willis untuk menanggulangi kenakalan remaja itu diperlukan teknik teknik sebagai beikut : 
Teknik behavior berasal dari dua konsep antara Pavlovian dari Ivan Pavlov dan dari Skinnerian dari B.F. Skinner. Dasar teori behavioral adalah bahwa perilaku dapat dipahami sebagai hasil kombinasi : 1) belajar waktu lalu dalam hubungannya dengan keadaan yang serupa, 2) keadaaan motivasional sekarang dan efeknya terhadap kepekaan terhadap lingkungan, 3) perbedaan biologic baik secara genetic maupun karena gangguan fisiologik. Menurut pendekatan behavior manusia adalah makhluk reaktif yang tingkah lakunya dikontrol oleh faktor-faktor dari luar. Manusia mengawali kehidupanya dengan bereaksi terhadap lingkungannya dan interaksi ini menghasilkan pola-pola perilaku yang kemudian membentuk kepribadian. Tingkah laku dapat dipelajari ketika individu berinteraksi dengan lingkungan melalui hukum-hukum belajar pembiasaan klasik, pembiasaan. (Willis, 1986:69)

Teknik behavioral terdiri dari dua jenis, antara lain teknik untuk meningkatkan tingkah laku dan untuk menurunkan tingkah laku. Teknik untuk meningkatkan tingkah laku adalah :

a. Penguatan positif

Penguatan positif adalah penguatan yang menyenangkan setelah tingkah laku yang diinginkan dilakukan yang bertujuan agar tingkah laku tersebut akan diulangdan meningkat diwaktu yang akan datang.

b. Kartu berharga (Token economy)

Token economy ini termasuk didalam penguatan, akan tetapi teknik ini merupakan strategi menghindari pemberian penguatan secara langsung. Token merupakan penghargaan yang dapat ditukar dengan berbagai barang yang diinginkan oleh klien.

c. Pembentukan tingkah laku (shaping)

Shaping adalah cara membentuk tingkah laku baru yang sebelumnya belum dilakukan dengan memberikan penghargaan secara sistematis dan langsung pada setiap tingkah laku dilakukan.

d. Pembuatan kontrak

Pembuatan kontrak adalah cara untuk mengatur kondisi sehingga klien menampilkan tingkah laku yang diinginkan berdasarkan kontrak antar klien dengan konselor. Sedangkan teknik behavior yang bertujuan untuk menurunkan tingkah laku antara lain : 


\section{1) Penghapusan}

Penghapusan adalah cara menghentikan penguatan pada tingkah laku yang sebelumnya diberi penguatan.

2) Time-out

Time-out adalah teknik menyisihkan peluang individu untuk mendapatkan penguatan positif. Teknik ini dapat digunakan di kelas, contohnya klien yang berperilaku tidak diharapkan diasingkan atau dipindahkan dari siswa-siswa yang lain pada waktu yang spesifik dan terbatas. Sehingga dalam keadaan terasing, individu tidak lagi berupaya untuk berperilaku yang dapat menarik perhatian guru dan teman-temanya.

3) Pembanjiran (floding)

Pembanjiran adalah membanjiri klien dengan situasi ataupenyebab kecemasan atau tingkah laku yang tidak dikehendaki, sampai klien sadar bahwa yang dicemaskan tidak terjadi. Akan tetapi pembanjiran dapat menimbulkan emosi yang sangat tinggi oleh sebab itu pembanjiran harus dilakukan dengan hatihati.

4) Penjenuhan (satiation)

Penjenuhan adalah cara membuat diri klien jenuh terhadap suatu tingkah laku yang tidak diinginkan, sehingga klien tidak akan melakukanya lagi.

5) Hukuman (punishment)

Hukuman merupakan intervensi operant-conditioning yang digunakan konselor untuk mengurangi tingkah laku yang tidak diinginkan. Hukuman ini terdiri dari stimulus yang tidak menyenangkan sebagai konsekuensi dari tingkah laku.

\section{6) Terapi Aversi}

Terapi aversi ini diharapkan terjadi proses pembalikan reinforcement dari perasaan senang atau bangga menyakiti orang lain, menjadi reinforcement seperti iba, takut, rasa bersalah melihar orang lain merasa sakit. Teknik ini merupakan teknik yang bertujuan untuk meredakan gangguan behavioral yang spesifik, melibatkan pengasosiasian tingkah laku simtomatik dengan suatu stimulus yang menyakitkan sampai tingkah laku yang tidak diinginkan tidak diulanggi lagi.

7) Desensitisasi sistematik 
Teknik ini dikembangkan oleh Wolpe yang mengatakan semua perilaku neorotic adalah ekspresi dari kecemasan. Dan respon terhadap kecemasan dapat dieliminasi dengan menemukan respon yang antagonistik. Rangsangan yang menimbulkan kecemasan secara berulang-ulang dipasangkan dengan keadaan relaksasi sehingga hubungan antara perangsangan dengan respon terhadap kecemasan dapat dihilangkan. Teknik ini digunakan untuk menghapus rasa cemas dan tingkah laku menghindar. Teknik ini melatih klien untuk santai dan mengasosiasikan keadaan santai dengan pengalaman pembangkit kecemasan yang dibayangkan atau divisualisasi.

E. Upaya Penanggulangan Kenakalan Masa Transisi Remaja Menurut Pendidikan Islam

1. Ikhtiar pencegahan yang bersifat umum meliputi:

a. Usaha pembinaan pribadi remaja sejak masih dalam kandungan melalui ibunya.

b. Setelah lahir, anak-anak perlu diasuh dan dididik dalam suasana yang stabil, menggembirakan serta optimisme.

c. Pendidikan dalam lingkungan sekolah, sekolah sebagai lingkungan kenakalan dua sebagai tempat pembentukan anak didik memegang peranan penting dalam mental, agama pengetahuan, dan keterampilan anak-anak didik. Kesalahan dan kekurangan-kekurangan dalam tubuh sekolah sebagai tempat mendidik bisa menyebabkan adanya peluang untuk timbulnya kenakalan remaja.

d. Pendidikan di luar sekolah dan rumah tangga. Dalam rangka mencegah atau mengurangi timbulnya kenakalan remaja akibat penggunaan waktu luang yang salah, maka pendidikan diluar instansi tersebut diatas mutlak perlu ditingkatkan.

e. Perbaikan lingkungan dan kondisi sosial.

2. Usaha-usaha Pencegahan yang bersifat khusus

Untuk menjamin ketertiban umum, khususnya dikalangan remaja perlu diusahakan kegiatan-kegiatan pencegahan yang bersifat khusus dan langsung sebagai berikut: (Arifin : 81)

a. Pengawasan

b. Bimbingan dan Penyuluhan. Bimbingan dan penyuluhan secara intensif 
terhadap orang tua dan para remaja agar orangtua dapat membimbing dan mendidik anak-anaknya secara sungguh-sungguh dan tepat agar para remaja tetap bertingkah laku yang wajar.

c. Pendekatan-pendekatan khusus terhadap remaja yang sudah menunjukkan gejala-gejala kenakalan perlu dilakukan sedini mungkin. Sedangkan tindakan represif terhadap remaja nakal perlu dilakukan pada saat-saat tertentu oleh instansi Kepolisian R.I bersama Badan Peradilan yang ada. Tindakan ini harus dijiwai dengan rasa kasih sayang yang bersifat mendidik terhadap mereka, oleh karena perilaku nakal yang mereka perbuat adalah akibat produk dari berbagai faktor intern dan extern remaja yang tidak disadari dapat merugikan pribadinya sendiri dan masyarakatnya.(Arifin : 82)

Jadi tindakan represif ini harus bersifat paedagogis, bukan bersifat "pelanggaran" ataupun "kejahatan". Semua usaha penanggulangan tersebut hendaknya didasarkan atas sikap dan pandangan bahwa remaja adalah hamba Allah yang masih dalam proses perkembangan/pertumbuhan menuju kematangan pribadinya yang membutuhkan bimbingan dari orang dewasa yang bertanggung jawab.

Menurut Daradjat, faktor-faktor terjadinya kenakalan remaja perlu mendapat penanggulangan sedini mungkin dari semua pihak, terutama orang tua, karena orang tua merupakan basis terdepan yang paling dapat mewarnai perilaku anak. Untuk itu suami istri harus bekerja sama sebagai mitra dalam menanggulangi kenakalan remaja. Yang perlu mendapat perhatian sebagai berikut:

Pertama, adalah soal peningkatan pendidikan Agama. Pendidikan agama harus dimulai dari rumah tangga, sejak si anak masih kecil. (Daradjat, 2000:120). Kadang-kadang orang menyangka bahwa pendidikan agama itu terbatas kepada ibadah, sembahyang, puasa, mengaji, dan sebagainya. Padahal pendidikan agama harus mencakup keseluruhan hidup dan menjadi pengendali dalam segala tindakan. Bagi orang yang menyangka bahwa agama itu sempit, maka pendidikan agama anak dicukupkannya saja dengan memanggil guru mengaji ke rumah, atau menyuruh anaknya pergi belajar mengaji ke sekolah atau ke tempat-tempat kursus lainnya. Padahal yang terpenting dalam pembinaan jiwa agama adalah keluarga dan harus terjadi melalui pengalaman hidup si anak dalam keluarga. Apa yang 
dilihat, didengar, dirasakan, oleh si anak sejak ia kecil akan memengaruhi pembinaan mentalnya.

Menurut Daradjat, supaya pembinaan jiwa agama itu betul-betul dapat membuat kuatnya jiwa si anak untuk menghadapi segala tantangan zaman dan suasana dikemudian hari, hendaknya ia dapat terbina sejak lahir, bahkan sejak dalam kandungan sampai ia mencapai usia dewasa dalam masyarakat. Untuk itu, kiranya pemerintah pemimpin masyarakat, alim ulama dan para pendidik juga mengadakan usaha peningkatan pendidikan agama bagi keluarga, sekolah dan masyarakat.

Perkembangan agama pada masa anak, terjadi melalui pengalaman hidupnya sejak kecil, dalam keluarga, di sekolah, dan dalam masyarakat lingkungan. Semakin banyak pengalaman yang bersifat agama (sesuai dengan ajaran agama) dan semakin banyak unsur agama, maka sikap, tindakan, kelakuan dan caranya menghadapi hidup akan sesuai dengan ajaran agama.( Daradjat, 2003:66)

Kedua, orang tua harus mengerti dasar-dasar pendidikan. Menurut Zakiah Daradjat, apabila pendidikan dan perlakuan yang diterima oleh si anak sejak kecil merupakan sebab-sebab pokok dari kenakalan anak-anak, maka setiap orangtua haruslah mengetahui dasar-dasar pengetahuan, minimal tentang jiwa si anak dan pokok-pokok pendidikan yang harus dilakukan dalam menghadapi bermacammacam sifat si anak. Untuk membekali orang tua dalam menghadapi persoalan anak-anaknya yang dalam umur remaja, orang tua perlu pengertian sederhana tentang ciri-ciri remaja atau psikologi remaja.

F. Upaya Keluarga Dalam Menanggulangi Kenakalan Masa Transisi Remaja

1. Kegagalan mencapai identitas peran dan lemahnya kontrol diri bisa dicegah atau diatasi dengan prinsip keteladanan. Remaja harus bisa mendapatkan sebanyak mungkin figur orang-orang dewasa yang telah melampaui masa remajanya dengan baik juga mereka yang berhasil memperbaiki diri setelah sebelumnya gagal pada tahap ini.

2. Adanya motivasi dari keluarga, guru, teman sebaya untuk melakukan point pertama.

3. Kemauan orangtua untuk membenahi kondisi keluarga sehingga tercipta keluarga yang harmonis, komunikatif, dan nyaman bagi remaja. 
4. Remaja pandai memilih teman dan lingkungan yang baik serta orangtua memberi arahan dengan siapa dan di komunitas mana remaja harus bergaul.

5. Remaja membentuk ketahanan diri agar tidak mudah terpengaruh jika ternyata teman sebaya atau komunitas yang ada tidak sesuai dengan harapan.

\section{KESIMPULAN}

A. Masa transisi remaja adalah masa perubahan tingkah laku yang dirasakan berbeda. Remaja memiliki kondisi dan energi yang sangat prima dan punya potensi serta fitalitas semangat juang dan daya patriotisme yang tinggi. Pada masa transisi ini remaja harus dikondisikan ke arah yang positif sehingga remaja tumbuh menjadi pribadi dewasa yang berperilaku mulia.

B. Masa Transisi remaja rentan terjadi kenakalan, baik yang berpotensi terjadinya tindak kriminal maupun tindak kejahatan biasa.

C. Mengatasi perilaku remaja masa transisi ini dapat dilakukan upaya preventif, kuratif dan refresif. Melalui pendekatan pendidikan Islam dilakukan dengan usaha yang bersifat umum yakni pendidikan islami semasa dalam kandungan, setelah lahir diberi kasih sayang serta pendidikan lingkungan di keluarga dan di masyarakat. Usaha khusus dilakukan dengan pengawasan, bimbingan dan penyuluhan serta tindakan khusus yang dibenarkan oleh perundang undangan yang berlaku. 


\section{DAFTAR PUSTAKA}

Al-Mighwar, Muhammad. Psikologi Remaja: Petunjuk Bagi Guru dan Orang Tua. Bandung: Pustaka Setia. 2006

D. Gunarsa, Singgih.. Psikologi perkembangan anak remaja. Jakarta: Gunung Mulia. 1994

Kartono, Kartini Psikologi Sosial 2, Kenakalan Remaja, Jakarta : Rajawali, 1986

Mappiare, Andi. Psikologi Remaja. Surabaya: Usaha Nasional. 1998

Mulyono, B. Pendekatan Analisis Kenakalan Remaja dan Penanggulangannya. Yogyakarta: Kanisius. 1995

Nur Asiyah, Ririn Upaya Penanggulangan Kenakalan Remaja SMUN di Kabupaten Boyolali. Skripsi tidak diterbitkan. Malang: Jurusan Pendidikan Pancasila dan Kewarganegaraan FIP IKIP Malang, 1996

Nurbani YS dan A Ariyadi W, Psikologi Anak dan Remaja, Yogyakarta: Aksara Indonesia, 2002

Prastuti, Endang. Profil Remaja dan Karakteristik Khasnya. Malang: Lembaga Pengabdian Kepada Masyarakat - IKIP Malang, 1997

Sarjono, Soekanto, Remaja dan Masalah masalahnya, Yogyakarta : Kanisius 1987

Sarwono, Sarlito Wirawan. Teori-teori Psikologi Sosial. Jakarta: Gunung Mulia, 1989

Soedarsono, Kenakalan Remaja. Jakarta: Rineka Cipta, 2004

Willis, Sofyan S, Remaja dan Masalahnya : Mengupas Berbagai Bentuk Kenakalan Remaja, Seperti Narkoba, Free Sex dan Pencegahannya. Bandung: Alfabeta, 2005

,Problem Remaja dan Pemecahnya, Bandung: Angkasa, 1986

Zakiah Daradjat, Ilmu Pendidikan Islam. Jakarta: Bumi Aksara, 2000 , Ilmu Jiwa Agama, Cet.16, Jakarta: Bulan Bintang, 2003 , Kesehatan Mental, Jakarta : Bumi Aksara, 2000 